\title{
Current State of and Recent Trends in Serum Lipid Levels in the General Japanese Population
}

\author{
Research Committee on Serum Lipid Level Survey 1990 in Japan
}

(Investigators are listed in the appendix.)

\begin{abstract}
To determine the recent serum lipid levels in the general Japanese population and trends in their changes over the past $\mathbf{3 0}$ years, a nationwide survey of serum lipid levels was conducted in $\mathbf{3 9}$ institutes from various districts around Japan. The total number of subjects was 34,815 , consisting of 20,279 men and 14,536 women aged 4 through 99 years. All the serum samples were collected and analyzed within one week at the Special Research Laboratory (Tokyo, Japan). In males, the mean serum cholesterol level showed a gradually increase from $170 \mathrm{mg} / \mathrm{dl}$ in the 0 - to 9-year-old age group to $198 \mathrm{mg} / \mathrm{dl}$ in the 50- to 59-year-old age group. There was a slight decrease after age 60 years. In females, the mean cholesterol level gradually rose with age from $173 \mathrm{mg} / \mathrm{dl}$ in the 0 - to 9 -year-old age group to $210 \mathrm{mg} / \mathrm{dl}$ in the 60- to 69-year-old age group, and fell to $207 \mathrm{mg} / \mathrm{dl}$ after 80 years of age. The mean HDL-cholesterol level in men gradually decreased with age from $60 \mathrm{mg} / \mathrm{dl}$ in the 0 - to 9 -year-old age group to $51 \mathrm{mg} / \mathrm{dl}$ in the 30- to 39-year-old age group, remained at this level up to 69 years of age, and then increased to $54 \mathrm{mg} / \mathrm{dl}$ for the above 80 years old group. The mean HDL-cholesterol level in women increased from $57 \mathrm{mg} / \mathrm{dl}$ in the 0 - to 9 -year-old age group to $62 \mathrm{mg} / \mathrm{dl}$ for the 20- to 29-year-old age group : then gradually decreased with age to $54 \mathrm{mg} / \mathrm{dl}$ in the 60 - to 79-yearold age group. The mean LDL-cholesterol level in men gradually increased with age from 98 $\mathrm{mg} / \mathrm{dl}$ in the 0- to 19-year-old age group to $122 \mathrm{mg} / \mathrm{dl}$ at 70-79 years of age. The mean LDLcholesterol level in women was low at $101-103 \mathrm{mg} / \mathrm{dl}$ up to 29 years of age, then it increased with age to $135 \mathrm{mg} / \mathrm{dl}$ in the 60- to 69-year-old age group. The serum cholesterol levels in 1970 and 1980 were higher than that in 1960, but in 1990 values similar to those in 1960 were observed in both men and women. The present results will become the standard serum lipid level data for the Japanese people, and succeeding 10-year surveys will clarify the trends of lipid levels in this country. $J$ Atheroscler Thromb, 1996; 2 : 122-132.
\end{abstract}

Key words: Serum lipid levels, Recent trends, General Japnese population

Comparisons among various populations throughout the world have revealed a direct correlation between serum cholesterol level and coronary heart disease (CHD) rate. The Seven Countries Study (1) showed that regions such as Finland and the USA which have the highest average dietary fat and cholesterol intakes also have the highest serum cholesterol values and incidence of $\mathrm{CHD}$. On the other hand, Japan which has lower dietary fat and lower choles-

Received April 5, 1995.

Address for correspondence: Hiroshi Mabuchi, M.D., The Second Department of Internal Medicine, Kanazawa University School of Medicine, Takara-machi 13-1, Kanazawa 920, Japan. terol intake was found to have lower serum cholesterol values and a correspondingly lower incidence of CHD. Japanese in the 1960s consumed very little dietary fat, $36 \mathrm{~g}$ per day in 1965, and both cholesterol levels and the incidence of CHD were low (1). Japanese who migrated to Hawaii and California showed higher levels of serum cholesterol and a higher incidence of CHD than people in Japan (2). Thus, dietary habits and other environmental factors rather than genetic background affect serum cholesterol levels and CHD mortality in the population. In the United States, during the period of 1960 through 1991, many changes in nutritional lifestyle, and medical therapeutic factors may have decreased serum total cholesterol levels among American adults (3). On the other hand, Japanese have adopted 
mixed dietary habits of a traditionally low fat and low cholesterol diet and a western style diet of relatively high fat and high cholesterol, and the serum cholesterol levels in the Japanese populations were found to have gradually increased over the 20 years from 1960 to 1980 by the 10-yearinterval national surveys of serum cholesterol levels conducted in 1960 (4), 1970 (5) and 1980 (6). This study is the fourth survey and reveals the most recent serum lipid levels in the Japanese general population and the trends of serum lipid levels over the 30 years from 1960 to 1990.

\section{Method}

\section{Design and Data Collection}

The Research Committee on Serum Lipid Level Survey 1990 in Japan organized the members of 39 institutes from various areas around Japan. The project was designed to produce representative data of serum lipid and apolipoprotein levels in the civilian Japanese population. The subjects were people receiving annual health examinations in general community, companies and schools, and not patients visiting hospitals. The total number of subjects was 34,815 , consisting of 20,279 men and 14,536 women.

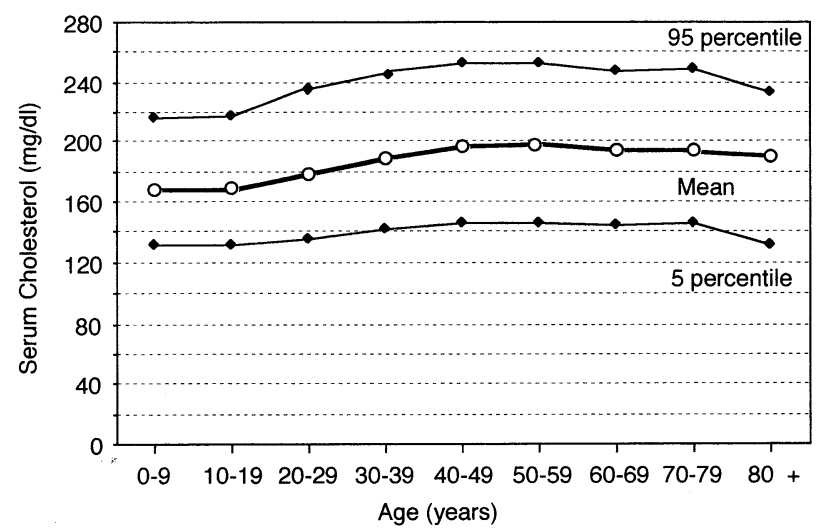

Fig. 1. Serum cholesterol for Japanese males, mean and percentile values for 10-year age groups.

\section{Laboratory Methods}

All serum samples were obtained in the fasting state. All lipid and lipoprotein analyses were conducted on venous blood samples within one week of collection at the Special Research Laboratory (SRL, Tokyo). Serum cholesterol (7) and triglyceride levels (8) were measured enzymatically. $\mathrm{HDL}$-cholesterol was measured in supernatants following precipitation of apo B-containing lipoproteins with heparincalcium chloride (9). LDL-cholesterol was calculated for samples with triglyceride levels of $400 \mathrm{mg} / \mathrm{dl}$ or less using the equation reported by Friedewald et al. (10). The results of lipid analyses in the four surveys were indirectly standardized according to the criteria of the CDC Lipid Standardization Program (11). There were no differences between the data obtained by Zak-Henly's method in 1960 (3) and 1970 (4), and those by the enzymatic methods used in 1980 (5) and 1990. Thus, the cholesterol levels in these four surveys appear to be comparable. In the present survey, apolipoproteins $A 1, B$ and $E$ and $L p$ (a) measurements were performed in 2,000 randomized samples, and these results will be reported in separate papers.

\section{Data Analyses}

The statistical analyses of the present data were performed by SAS statistical package in the Information Processing Center, Aichi Medical University. The mean and standard deviation (SD) were obtained excluding extreme cases outside two SDs after the initial calculation. One of the reasons for the operation was comparability with the previous data in 1960 to 1980.

\section{Results}

Table 1 and Fig. 1 show the age-specific means, standard deviations, medians and percentiles of serum total cholesterol levels by age group in males, and Table 2 and Fig. 2 those in females.

In the males, the age-specific mean serum cholesterol levels gradually increased from $170 \mathrm{mg} / \mathrm{dl}$ in the $0_{-}^{-}$to 9 year-old age group to $198 \mathrm{mg} / \mathrm{dl}$ in the 50 - to 59 -year-old age group. There was a slight decrease after age 60 . The ninety-fifth percentile was $216 \mathrm{mg} / \mathrm{dl}$ in the 0 - to 9 -year-old

Table 1. Serum total cholesterol $(\mathrm{mg} / \mathrm{dl})$ for normal Japanese men.

\begin{tabular}{crccccccccc}
\hline \multirow{2}{*}{$\begin{array}{c}\text { Age } \\
\text { (years) }\end{array}$} & & $\mathrm{n}$ & & & \multicolumn{7}{c}{ Percentile } \\
\cline { 6 - 10 } & & Mean & $\mathrm{SD}$ & 5 & 10 & 25 & 50 & 75 & 90 & 95 \\
\hline $0-9$ & 517 & 170 & 25 & 132 & 140 & 152 & 167 & 186 & 202 & 216 \\
$10-19$ & 1463 & 170 & 26 & 132 & 138 & 151 & 168 & 188 & 207 & 217 \\
$20-29$ & 755 & 180 & 30 & 135 & 144 & 159 & 177 & 197 & 222 & 237 \\
$30-39$ & 2318 & 191 & 32 & 142 & 150 & 167 & 188 & 214 & 236 & 248 \\
$40-49$ & 6606 & 196 & 31 & 146 & 156 & 174 & 195 & 218 & 239 & 252 \\
$50-59$ & 4708 & 198 & 31 & 146 & 157 & 176 & 198 & 221 & 241 & 252 \\
$60-69$ & 2409 & 194 & 31 & 144 & 153 & 171 & 194 & 216 & 253 & 247 \\
$70-79$ & 568 & 194 & 30 & 146 & 154 & 172 & 192 & 214 & 234 & 249 \\
$80+$ & 60 & 191 & 30 & 132 & 152 & 172 & 195 & 215 & 223 & 233 \\
\hline
\end{tabular}


Table 2. Serum total cholesterol $(\mathrm{mg} / \mathrm{dl})$ for normal Japanese women.

\begin{tabular}{ccccccccccc}
\hline \multirow{2}{*}{$\begin{array}{c}\text { Age } \\
\text { (years) }\end{array}$} & $\mathrm{n}$ & & & \multicolumn{7}{c}{ Percentile } \\
\cline { 6 - 11 } & Mean & $\mathrm{SD}$ & 5 & 10 & 25 & 50 & 75 & 90 & 95 \\
\hline $0-9$ & 473 & 173 & 24 & 135 & 143 & 155 & 173 & 188 & 206 & 217 \\
$10-19$ & 1440 & 177 & 27 & 137 & 144 & 159 & 175 & 194 & 213 & 225 \\
$20-29$ & 480 & 177 & 29 & 135 & 142 & 155 & 176 & 197 & 216 & 231 \\
$30-39$ & 1395 & 179 & 28 & 137 & 144 & 159 & 176 & 196 & 216 & 229 \\
$40-49$ & 3432 & 191 & 30 & 143 & 153 & 169 & 189 & 211 & 233 & 245 \\
$50-59$ & 3386 & 208 & 31 & 156 & 168 & 187 & 209 & 231 & 250 & 259 \\
$60-69$ & 2535 & 210 & 30 & 159 & 170 & 189 & 211 & 233 & 251 & 260 \\
$70-79$ & 618 & 209 & 31 & 159 & 168 & 189 & 210 & 232 & 250 & 259 \\
$80+$ & 71 & 207 & 37 & 138 & 156 & 172 & 217 & 239 & 251 & 262 \\
\hline
\end{tabular}

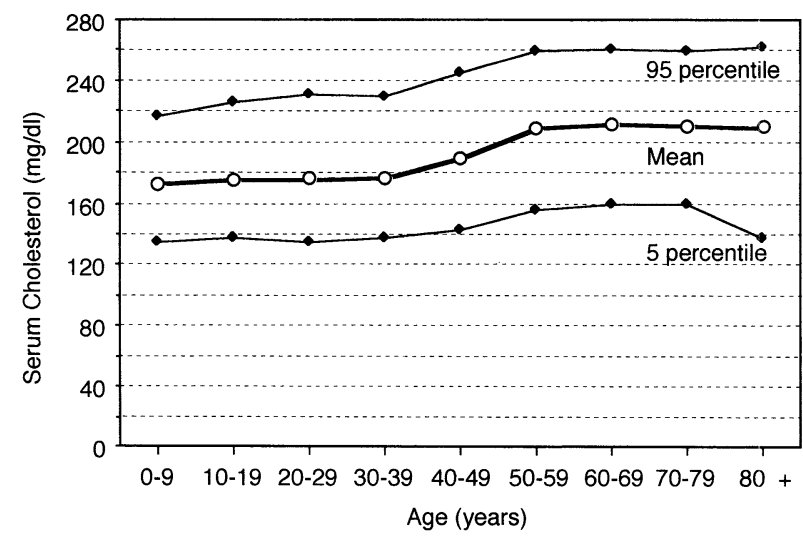

Fig. 2. Serum cholesterol for Japanese females, mean and percentile values for 10 -year age groups.

age group, increased to $252 \mathrm{mg} / \mathrm{dl}$ in the 40 - to 59 -year-old age group, and slightly decreased after age 60 .

In females, the mean cholesterol levels gradually rose from $173 \mathrm{mg} / \mathrm{dl}$ in the 0- to 9-year-old age group to $210 \mathrm{mg} / \mathrm{dl}$ in the 60- to 69-year-old age group, and fell to $207 \mathrm{mg} / \mathrm{dl}$ after age 80 . The 95th percentile rose from $217 \mathrm{mg} / \mathrm{dl}$ in the 0 to 9 -year-old age group to $231 \mathrm{mg} / \mathrm{dl}$ in the 20- to 29-yearold age group, dipped slightly in the 30- to 39-year-old age group, and thereafter increased to $262 \mathrm{mg} / \mathrm{dl}$ in the above 80-year-old age group.
Table 3 and Fig. 3 show the age-specific means, standard deviations, medians and percentiles of serum triglyceride levels in males, and Table 4 and Fig. 4 those in females. The age-specific mean triglyceride values in men increased from $55 \mathrm{mg} / \mathrm{dl}$ in the 0- to 9-year-old age group to $109 \mathrm{mg} /$ $\mathrm{dl}$ in the 30- to 39-year-old age group, and remained unchanged up to 69 years of age, followed by a decline to $88 \mathrm{mg} / \mathrm{dl}$ above 80 years old. In females, the age-specific mean triglyceride levels increased gradually from $56 \mathrm{mg} / \mathrm{dl}$ in the 0 - to 9 -year-old age group to $105 \mathrm{mg} / \mathrm{dl}$ in the 60 - to

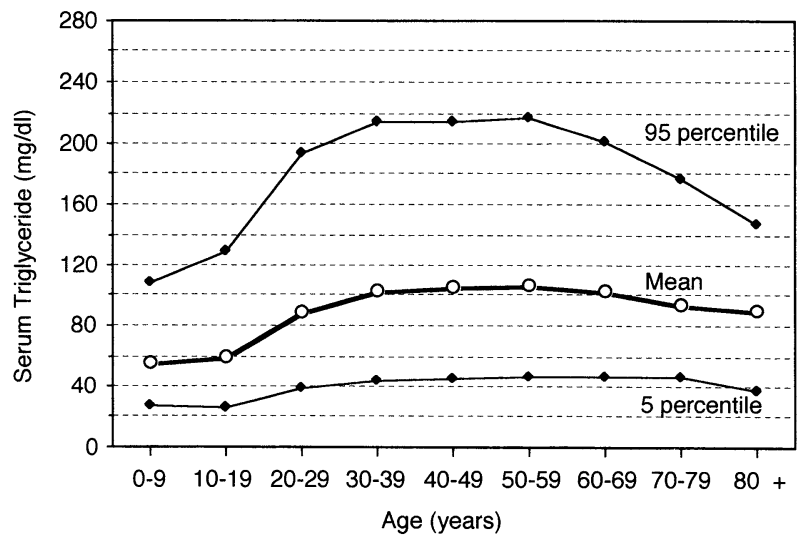

Fig. 3. Serum triglyceride for Japanese males, mean and percentile values for 10 -year age groups.

Table 3. Serum triglyceride $(\mathrm{mg} / \mathrm{dl})$ for normal Japanese men.

\begin{tabular}{|c|c|c|c|c|c|c|c|c|c|c|}
\hline \multirow{2}{*}{$\begin{array}{c}\text { Age } \\
\text { (years) }\end{array}$} & \multirow[b]{2}{*}{$n$} & \multirow[b]{2}{*}{ Mean } & \multirow[b]{2}{*}{ SD } & \multicolumn{7}{|c|}{ Percentile } \\
\hline & & & & 5 & 10 & 25 & 50 & 75 & 90 & 95 \\
\hline $0-9$ & 528 & 55 & 31 & 27 & 28 & 36 & 48 & 64 & 90 & 109 \\
\hline $10-19$ & 1495 & 61 & 34 & 26 & 30 & 39 & 52 & 73 & 102 & 129 \\
\hline $20-29$ & 763 & 94 & 47 & 39 & 45 & 59 & 81 & 119 & 159 & 193 \\
\hline $30-39$ & 2234 & 109 & 52 & 44 & 51 & 69 & 95 & 138 & 187 & 214 \\
\hline $40-49$ & 6489 & 109 & 51 & 45 & 53 & 71 & 98 & 138 & 186 & 214 \\
\hline $50-59$ & 4613 & 110 & 51 & 47 & 54 & 72 & 99 & 139 & 184 & 217 \\
\hline $60-69$ & 2391 & 105 & 47 & 47 & 55 & 71 & 95 & 130 & 172 & 201 \\
\hline $70-79$ & 579 & 95 & 40 & 47 & 51 & 66 & 87 & 119 & 151 & 177 \\
\hline $80+$ & 65 & 88 & 37 & 37 & 48 & 63 & 83 & 107 & 135 & 147 \\
\hline
\end{tabular}


Table 4. Serum triglyceride (mg/dl) for normal Japanese women.

\begin{tabular}{|c|c|c|c|c|c|c|c|c|c|c|}
\hline \multirow{2}{*}{$\begin{array}{c}\text { Age } \\
\text { (years) }\end{array}$} & \multirow[b]{2}{*}{$\mathrm{n}$} & \multirow[b]{2}{*}{ Mean } & \multirow[b]{2}{*}{ SD } & \multicolumn{7}{|c|}{ Percentile } \\
\hline & & & & 5 & 10 & 25 & 50 & 75 & 90 & 95 \\
\hline $0-9$ & 481 & 56 & 25 & 27 & 31 & 39 & 50 & 70 & 90 & 107 \\
\hline $10-19$ & 1459 & 63 & 31 & 30 & 34 & 43 & 56 & 74 & 99 & 121 \\
\hline $20-29$ & 494 & 63 & 29 & 31 & 34 & 43 & 57 & 76 & 96 & 117 \\
\hline $30-39$ & 1417 & 69 & 34 & 33 & 37 & 46 & 60 & 80 & 107 & 138 \\
\hline $40-49$ & 3490 & 77 & 37 & 37 & 42 & 52 & 69 & 92 & 122 & 154 \\
\hline $50-59$ & 3535 & 96 & 45 & 44 & 50 & 63 & 85 & 119 & 158 & 186 \\
\hline $60-69$ & 2637 & 105 & 46 & 48 & 55 & 71 & 95 & 129 & 171 & 197 \\
\hline $70-79$ & 639 & 102 & 44 & 48 & 56 & 71 & 92 & 124 & 159 & 196 \\
\hline $80+$ & 74 & 99 & 41 & 51 & 57 & 70 & 90 & 117 & 157 & 183 \\
\hline
\end{tabular}

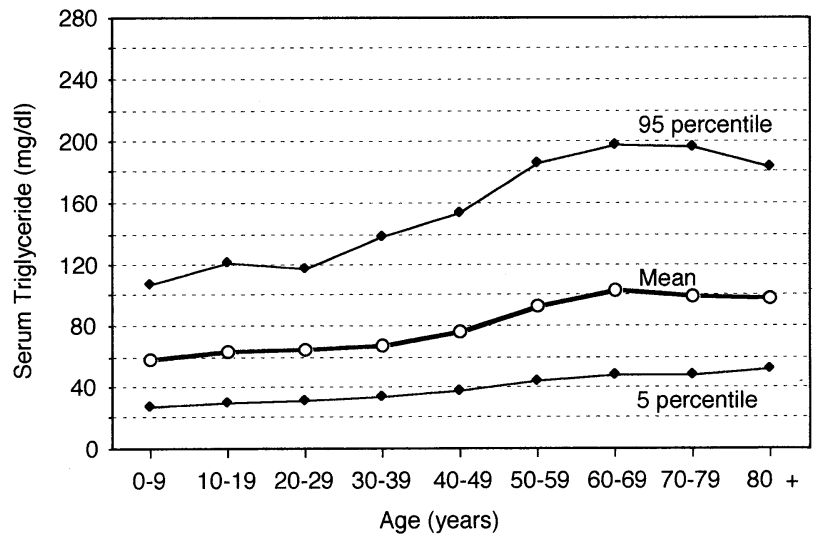

Fig. 4. Serum triglyceride for Japanese females, mean and percentile values for 10 -year age groups.

69-year-old age group, and then declined to $99 \mathrm{mg} / \mathrm{dl}$ above 80 years of age.

Table 5 and Fig. 5 show the age-specific means, standard deviations, medians and percentiles in serum HDL-cholesterol levels in males, and Table 6 and Fig. 6 those in females. The age-specific mean HDL-cholesterol levels in men gradually decreased from $60 \mathrm{mg} / \mathrm{dl}$ in the 0- to 9-yearold age group to $51 \mathrm{mg} / \mathrm{dl}$ in the 30 - to 39-year-old age group, and remained at this level up to 69 years of age, and then increased to $54 \mathrm{mg} / \mathrm{dl}$ in the above 80 -year-old age group. The mean HDL-cholesterol levels in women increased from $57 \mathrm{mg} / \mathrm{dl}$ in the 0- to 9-year-old age group to $62 \mathrm{mg} / \mathrm{dl}$ in the 20- to 29-year-old age group, and gradually decreased to $54 \mathrm{mg} / \mathrm{dl}$ in the 60- to 79-year-old age group.

Table 7 and Fig. 7 show the age-specific means, standard deviations, medians and percentiles in serum LDL-cholesterol levels in males, and Table 8 and Fig. 8 those in females. The age-specific mean LDL-cholesterol levels for men gradually increased from $98 \mathrm{mg} / \mathrm{dl}$ in the 0- to 19-yearold age group to $122 \mathrm{mg} / \mathrm{dl}$ in the 70 - to 79 -year-old age

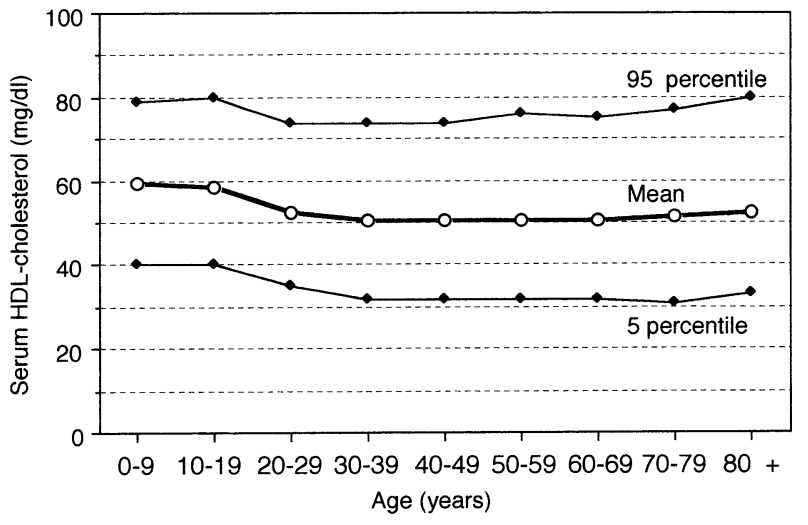

Fig. 5. Serum HDL-cholesterol for Japanese males, mean and percentile values for 10 -year age groups.

Table 5. Serum HDL-cholesterol (mg/dl) for normal Japanese men.

\begin{tabular}{ccccccccccc}
\hline \multirow{2}{*}{$\begin{array}{c}\text { Age } \\
\text { (years) }\end{array}$} & & $\mathrm{n}$ & & \multicolumn{7}{c}{ Percentile } \\
\cline { 6 - 11 } & Mean & SD & 5 & 10 & 25 & 50 & 75 & 90 & 95 \\
\hline $0-9$ & 503 & 60 & 12 & 40 & 44 & 51 & 59 & 69 & 76 & 79 \\
$10-19$ & 1462 & 59 & 12 & 40 & 44 & 50 & 58 & 67 & 75 & 80 \\
$20-29$ & 764 & 53 & 12 & 35 & 39 & 45 & 52 & 60 & 68 & 74 \\
$30-39$ & 2328 & 51 & 13 & 32 & 36 & 42 & 50 & 59 & 69 & 74 \\
$40-49$ & 6633 & 51 & 13 & 32 & 35 & 42 & 50 & 59 & 69 & 74 \\
$50-59$ & 4683 & 51 & 13 & 32 & 35 & 42 & 50 & 59 & 70 & 76 \\
$60-69$ & 2389 & 51 & 13 & 32 & 36 & 42 & 50 & 59 & 69 & 75 \\
$70-79$ & 551 & 52 & 14 & 31 & 36 & 42 & 51 & 63 & 73 & 77 \\
$80+$ & 64 & 54 & 15 & 33 & 36 & 42 & 52 & 65 & 74 & 80 \\
\hline
\end{tabular}


Table 6. Serum HDL-cholesterol $(\mathrm{mg} / \mathrm{dl})$ for normal Japanese women.

\begin{tabular}{|c|c|c|c|c|c|c|c|c|c|c|}
\hline \multirow{2}{*}{$\begin{array}{c}\text { Age } \\
\text { (years) }\end{array}$} & \multirow[b]{2}{*}{$n$} & \multirow[b]{2}{*}{ Mean } & \multirow[b]{2}{*}{ SD } & \multicolumn{7}{|c|}{ Percentile } \\
\hline & & & & 5 & 10 & 25 & 50 & 75 & 90 & 95 \\
\hline $0-9$ & 466 & 57 & 12 & 37 & 43 & 49 & 57 & 65 & 72 & 78 \\
\hline $10-19$ & 1410 & 60 & 12 & 41 & 45 & 52 & 59 & 67 & 75 & 79 \\
\hline $20-29$ & 476 & 62 & 12 & 44 & 48 & 54 & 62 & 70 & 78 & 82 \\
\hline $30-39$ & 1363 & 58 & 12 & 40 & 43 & 51 & 58 & 67 & 74 & 78 \\
\hline $40-49$ & 3342 & 58 & 12 & 37 & 42 & 49 & 57 & 66 & 74 & 79 \\
\hline 50-59 & 3438 & 56 & 13 & 36 & 40 & 47 & 55 & 65 & 73 & 78 \\
\hline $60-69$ & 2582 & 54 & 12 & 35 & 38 & 45 & 53 & 62 & 71 & 76 \\
\hline $70-79$ & 625 & 54 & 13 & 33 & 37 & 45 & 53 & 62 & 71 & 76 \\
\hline $80+$ & 75 & 56 & 14 & 33 & 39 & 46 & 55 & 64 & 77 & 81 \\
\hline
\end{tabular}

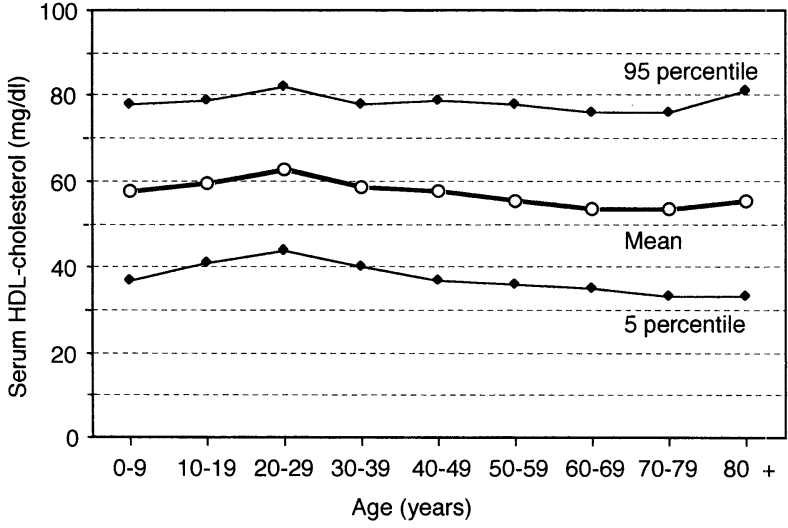

Fig. 6. Serum HDL-cholesterol for Japanese females, mean and percentile values for 10 -year age groups.

group. The age-specific mean LDL-cholesterol level for women increased from $103 \mathrm{mg} / \mathrm{dl}$ in the 0 - to 19-year-old age group to $135 \mathrm{mg} / \mathrm{dl}$ in the 60- to 69-year-old age group, and then decreased slightly thereafter.

Table 9 shows the prevalence of each blood cholesterol level in Japanese men and women. The age-adjusted proportions of adults 20 through 79 years of age with serum total cholesterol levels of $220 \mathrm{mg} / \mathrm{dl}$ and higher were $20.1 \%$ for men and $24.6 \%$ for women. Those with serum total cholesterol levels of $240 \mathrm{mg} / \mathrm{dl}$ and higher were $8.2 \%$ for

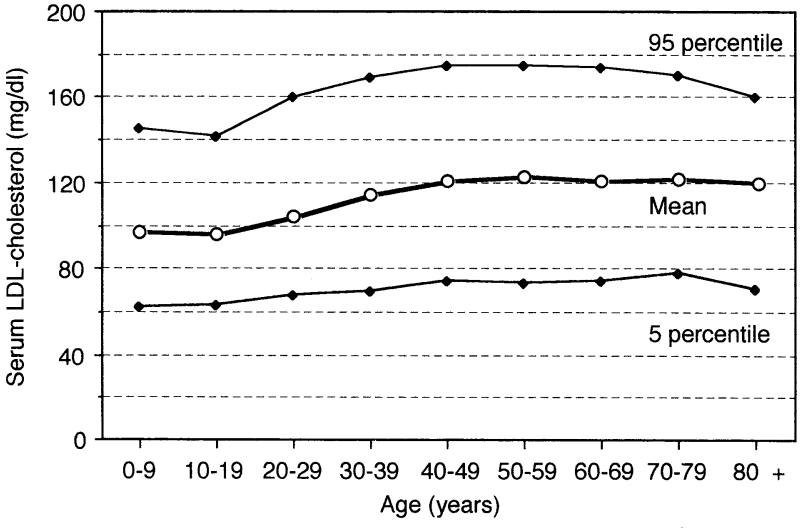

Fig. 7. Serum LDL-cholesterol for Japanese males, mean and percentile values for 10-year age groups.

men and $11.3 \%$ for women.

Table 10 shows the prevalence of each blood triglyceride level. The age-adjusted proportions of adults from 20 through 79 years of age with serum triglyceride levels of 200 $\mathrm{mg} / \mathrm{dl}$ and higher were $5.7 \%$ for men and $2.7 \%$ for women.

Table 11 shows the prevalence of high and low HDLcholesterol. The age-adjusted proportions of adults from 20 through 79 years of age with a low HDL-cholesterol level of less than $35 \mathrm{mg} / \mathrm{dl}$ were $8.4 \%$ for men and $3.6 \%$ for women. Those with high HDL-cholesterol levels higher

Table 7. Serum LDL-cholesterol $(\mathrm{mg} / \mathrm{dl})$ for normal Japanese men.

\begin{tabular}{|c|c|c|c|c|c|c|c|c|c|c|}
\hline \multirow{2}{*}{$\begin{array}{c}\text { Age } \\
\text { (years) }\end{array}$} & \multirow[b]{2}{*}{$\mathrm{n}$} & \multirow[b]{2}{*}{ Mean } & \multirow[b]{2}{*}{ SD } & \multicolumn{7}{|c|}{ Percentile } \\
\hline & & & & 5 & 10 & 25 & 50 & 75 & 90 & 95 \\
\hline $0-9$ & 522 & 98 & 23 & 62 & 70 & 83 & 96 & 111 & 127 & 145 \\
\hline $10-19$ & 1489 & 98 & 24 & 63 & 70 & 82 & 95 & 112 & 130 & 141 \\
\hline $20-29$ & 765 & 107 & 28 & 67 & 73 & 87 & 103 & 125 & 146 & 159 \\
\hline $30-39$ & 2323 & 116 & 30 & 69 & 78 & 94 & 113 & 136 & 159 & 169 \\
\hline $40-49$ & 6598 & 121 & 30 & 74 & 83 & 100 & 120 & 142 & 163 & 174 \\
\hline $50-59$ & 4699 & 122 & 30 & 73 & 82 & 101 & 122 & 144 & 164 & 174 \\
\hline $60-69$ & 2401 & 121 & 30 & 74 & 82 & 99 & 120 & 142 & 162 & 173 \\
\hline $70-79$ & 573 & 122 & 29 & 77 & 87 & 101 & 121 & 143 & 160 & 170 \\
\hline $80+$ & 63 & 120 & 30 & 70 & 77 & 101 & 122 & 144 & 154 & 159 \\
\hline
\end{tabular}


Table 8. Serum LDL-cholesterol (mg/dl) for normal Japanese women.

\begin{tabular}{|c|c|c|c|c|c|c|c|c|c|c|}
\hline \multirow{2}{*}{$\begin{array}{c}\text { Age } \\
\text { (years) }\end{array}$} & \multirow[b]{2}{*}{$\mathrm{n}$} & \multirow[b]{2}{*}{ Mean } & \multirow[b]{2}{*}{ SD } & \multicolumn{7}{|c|}{ Percentile } \\
\hline & & & & 5 & 10 & 25 & 50 & 75 & 90 & 95 \\
\hline $0-9$ & 477 & 103 & 22 & 67 & 77 & 88 & 101 & 117 & 133 & 140 \\
\hline $10-19$ & 1451 & 103 & 24 & 68 & 76 & 86 & 102 & 117 & 134 & 146 \\
\hline $20-29$ & 491 & 101 & 27 & 61 & 69 & 84 & 99 & 115 & 137 & 156 \\
\hline $30-39$ & 1408 & 105 & 26 & 68 & 74 & 87 & 103 & 122 & 141 & 155 \\
\hline $40-49$ & 3439 & 117 & 29 & 75 & 82 & 97 & 115 & 136 & 156 & 171 \\
\hline $50-59$ & 3395 & 133 & 29 & 85 & 94 & 112 & 133 & 154 & 172 & 181 \\
\hline $60-69$ & 2536 & 135 & 29 & 87 & 97 & 115 & 135 & 156 & 174 & 183 \\
\hline $70-79$ & 618 & 134 & 28 & 87 & 97 & 115 & 134 & 153 & 171 & 182 \\
\hline $80+$ & 75 & 133 & 33 & 73 & 82 & 108 & 141 & 162 & 171 & 178 \\
\hline
\end{tabular}

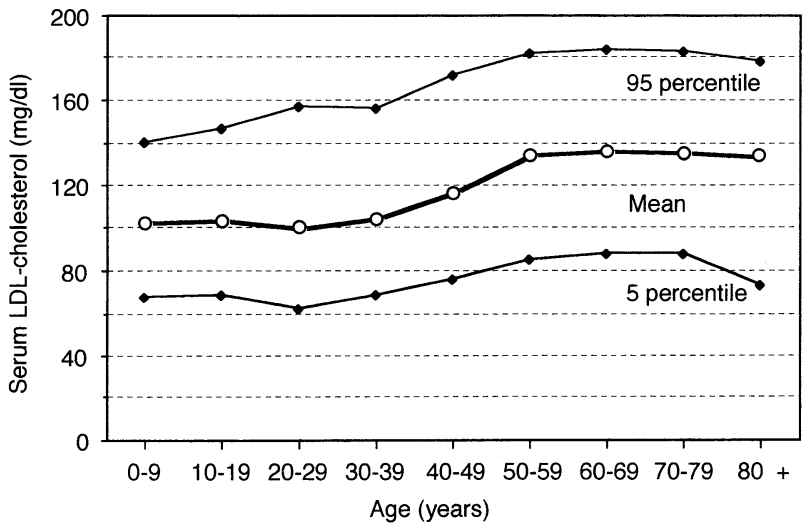

Fig. 8. Serum LDL-cholesterol for Japanese females, mean and percentile values for 10 -year age groups.

than $60 \mathrm{mg} / \mathrm{dl}$ were $25.0 \%$ for men and $39.6 \%$ for women.

Table 12 shows the prevalence of hyper-LDL-cholesterolemia in men and women. The age-adjusted proportions of adults from 20 through 79 years of age with a high LDLcholesterol higher than 130 and $160 \mathrm{mg} / \mathrm{dl}$ were $34.0 \%$ and $9.8 \%$ for men and $37.9 \%$ and $12.1 \%$ for women, respectively.

The trends in mean serum cholesterol level in the Japanese population in the previous four surveys were compared. The serum cholesterol levels in 1970 and 1980 were higher than that in 1960 , but that in 1990 was similar to the value in 1960 in both men and women (Table 13). The serum triglyceride level in men increased in 1980, but decreased in 1990 (Table 14). However, in women the triglyceride level gradually decreased with time.

The mean age-adjusted serum cholesterol level in Japan increased gradually from 1970 to 1980 with no further increase seen in 1990, while the levels in USA gradually decreased during this 30 year period (3), with the difference between the two countries becoming smaller (Table 15).

\section{Discussion}

Various factors influence serum cholesterol levels in the populations, especially intakes of saturated fat and cholesterol (1). The extent to which trends in the composition of dietary fat and cholesterol in the US adult population are consistent with the decline in serum cholesterol levels is unclear (3). Continuing surveys of food intake by individuals will provide updated dietary information to explore this issue. Due to westernization, especially changes in dietary habits, the serum cholesterol levels in the Japanese populations rose from 1960-1980, but after 1980, dietary fat intake, particularly animal fat intake reached a plateau, as did serum cholesterol levels $(12,13)$.

Table 16 shows the changes in dietary intake of nutrients in the Japanese population (12). Compared with the data

Table 9. Prevalence (\%) of each cholesterol level $(\mathrm{mg} / \mathrm{dl})$ in Japanese men and women.

\begin{tabular}{|c|c|c|c|c|c|c|c|c|c|c|c|c|c|c|c|c|c|c|}
\hline \multirow{2}{*}{$\begin{array}{c}\text { Age } \\
\text { (years) }\end{array}$} & \multicolumn{9}{|c|}{ Men } & \multicolumn{9}{|c|}{ Women } \\
\hline & $n$ & $160<$ & $180<$ & $200<$ & $220<$ & $230<$ & $240<$ & $250<$ & $260<$ & $\mathrm{n}$ & $160<$ & $180<$ & $200<$ & $220<$ & $230<$ & $240<$ & $250<$ & $260<$ \\
\hline $0-9$ & 517 & 63.2 & 30.6 & 11.2 & 4.1 & 2.7 & 1.4 & 1.0 & 0.1 & 473 & 66.2 & 34.7 & 13.9 & 4.2 & 2.1 & 0.8 & 0 & 0 \\
\hline $10-19$ & 1463 & 61.4 & 33.2 & 14.0 & 4.3 & 2.1 & 1.0 & 0.2 & 0.0 & 1440 & 71.9 & 42.2 & 19.7 & 6.3 & 3.5 & 1.5 & 0.8 & 0.5 \\
\hline $20-29$ & 755 & 73.0 & 43.3 & 23.6 & 11.6 & 6.9 & 4.4 & 2.8 & 0.3 & 480 & 66.5 & 43.5 & 21.8 & 8.3 & 5.2 & 2.9 & 1.7 & 0.4 \\
\hline $30-3$ & 2318 & 81 & 59.0 & 38.3 & 20.1 & 13.9 & 8.4 & 4.4 & 1.8 & 1395 & 72.9 & 43.8 & 21.0 & 8.2 & 4.7 & 2.6 & 1.7 & 0.7 \\
\hline $40-49$ & 6606 & 86.8 & 67.4 & 44.8 & 23.7 & 16.1 & 10.0 & 5.9 & 2. & 3432 & 84.5 & 61.9 & 37.7 & 17.0 & 11.8 & 6.8 & 3.8 & 1.2 \\
\hline $50-59$ & 4708 & 88.1 & 70.4 & 47.0 & 26.0 & 17.2 & 11.3 & 6.0 & 2.4 & 3386 & 93.4 & 80.2 & 60.7 & 37.5 & 26.6 & 17.4 & 10.4 & 4.4 \\
\hline $60-69$ & 2409 & 85.1 & 65.0 & 42.6 & 21.8 & 13.7 & 7.8 & 4.2 & 1.7 & 2535 & 94.4 & 83.0 & 64.0 & 38.6 & 30.0 & 19.1 & 11.2 & 5.0 \\
\hline $70-79$ & 568 & 84.7 & 65.5 & 41.4 & 20.3 & 12.9 & 7.4 & 4.8 & 1.2 & 618 & 94.0 & 81.7 & 62.9 & 37.1 & 27.0 & 19.1 & 10.0 & 4.3 \\
\hline $80+$ & 60 & 86.7 & 61.7 & 48.2 & 16.6 & 5.0 & 3.3 & 1.7 & 0.0 & 71 & 88.7 & 73.2 & 63.3 & 43.6 & 28.2 & 21.1 & 12.7 & 5.6 \\
\hline $20-79$ & 17364 & 83.3 & 61.8 & 39.6 & 20.6 & 13.5 & 8.2 & 4.7 & 1.6 & 11846 & 84.3 & 65.7 & 44.7 & 24.6 & 17.6 & 11.3 & 6.5 & 2.7 \\
\hline
\end{tabular}


Table 10. Prevalence (\%) of hypertriglyceridemia $(\mathrm{mg} / \mathrm{dl})$ in Japanese men and women.

\begin{tabular}{crrrrrrrrrr}
\hline \multirow{2}{*}{$\begin{array}{c}\text { Age } \\
\text { (years) }\end{array}$} & \multicolumn{1}{c}{$\mathrm{n}$} & $150<$ & $170<$ & $200<$ & $250<$ & \multicolumn{1}{c}{ Women } \\
\hline $0-9$ & 528 & 1.4 & 1.1 & 0.9 & 0.3 & 481 & 0.2 & 0.0 & 0.0 & 0.0 \\
$10-19$ & 1495 & 3.2 & 2.3 & 0.9 & 0.0 & 1459 & 2.1 & 1.2 & 0.6 & 0.0 \\
$20-29$ & 763 & 13.3 & 8.8 & 4.7 & 0.1 & 494 & 2.0 & 1.4 & 0.6 & 0.0 \\
$30-39$ & 2234 & 20.5 & 14.5 & 7.4 & 1.6 & 1417 & 3.7 & 2.6 & 1.1 & 0.2 \\
$40-49$ & 6489 & 20.3 & 14.2 & 7.5 & 1.4 & 3490 & 5.4 & 3.3 & 1.5 & 0.1 \\
$50-59$ & 4613 & 20.2 & 13.4 & 7.2 & 1.4 & 3535 & 12.4 & 7.9 & 3.6 & 0.5 \\
$60-69$ & 2391 & 16.4 & 10.4 & 5.4 & 1.1 & 2637 & 15.7 & 10.3 & 4.6 & 0.7 \\
$70-79$ & 579 & 10.4 & 6.2 & 1.9 & 0.3 & 639 & 13.5 & 7.4 & 4.5 & 0.4 \\
$80+$ & 65 & 4.6 & 4.6 & 1.5 & 0.0 & 74 & 10.8 & 5.4 & 4.1 & 0.0 \\
\hline $20-79$ & 17069 & 16.9 & 11.3 & 5.7 & 1.0 & 12212 & 8.8 & 5.5 & 2.7 & 0.3 \\
\hline
\end{tabular}

Table 11. Prevalence (\%) of low- and high-HDL-cholesterolemia $(\mathrm{mg} / \mathrm{dl})$ in Japanese men and women.

\begin{tabular}{|c|c|c|c|c|c|c|c|c|c|c|c|c|c|c|}
\hline \multirow{2}{*}{$\begin{array}{c}\text { Age } \\
\text { (years) }\end{array}$} & \multicolumn{7}{|c|}{ Men } & \multicolumn{7}{|c|}{ Women } \\
\hline & $\mathrm{n}$ & $<30$ & $<35$ & $<40$ & $50<$ & $60<$ & $70<$ & $n$ & $<30$ & $<35$ & $<40$ & $50<$ & $60<$ & $70<$ \\
\hline $0-9$ & 503 & 0.0 & 2.0 & 5.5 & 22.5 & 47.9 & 21.3 & 468 & 0.4 & 2.4 & 7.2 & 27.8 & 40.8 & 13.9 \\
\hline $10-19$ & 1462 & 0.2 & 1.1 & 4.8 & 25.0 & 41.5 & 18.7 & 1410 & 0.1 & 1.1 & 3.7 & 20.1 & 47.9 & 19.1 \\
\hline $20-29$ & 764 & 0.9 & 5.5 & 12.1 & 42.0 & 24.9 & 8.5 & 476 & 0.2 & 1.1 & 3.1 & 14.9 & 56.3 & 23.9 \\
\hline $30-39$ & 2328 & 3.0 & 8.7 & 19.4 & 49.6 & 23.2 & 8.3 & 1363 & 0.5 & 1.7 & 4.6 & 23.0 & 44.1 & 17.2 \\
\hline $40-49$ & 6633 & 2.7 & 9.3 & 20.3 & 51.2 & 23.7 & 8.7 & 3342 & 0.7 & 3.3 & 7.2 & 26.7 & 41.5 & 16.2 \\
\hline $50-59$ & 4683 & 3.0 & 9.7 & 20.5 & 50.2 & 24.9 & 9.4 & 3438 & 0.9 & 3.9 & 9.9 & 34.6 & 36.0 & 15.2 \\
\hline $60-69$ & 2389 & 2.8 & 8.6 & 19.5 & 49.8 & 23.6 & 9.3 & 2582 & 1.2 & 5.1 & 12.0 & 40.2 & 30.3 & 11.3 \\
\hline $70-79$ & 551 & 3.4 & 8.7 & 19.1 & 47.7 & 29.9 & 13.4 & 625 & 1.4 & 6.7 & 14.0 & 40.3 & 29.6 & 10.2 \\
\hline $80+$ & 64 & 4.6 & 6.3 & 18.6 & 46.9 & 32.8 & 18.8 & 75 & 2.6 & 6.7 & 10.6 & 33.3 & 41.3 & 16.0 \\
\hline $20-79$ & 17348 & 2.6 & 8.4 & 18.5 & 48.4 & 25.0 & 9.6 & 11826 & 0.8 & 3.6 & 8.5 & 30.0 & 39.6 & 15.7 \\
\hline
\end{tabular}

Table 12. Prevalence (\%) of hyper-LDL-cholesterolemia $(\mathrm{mg} / \mathrm{dl})$ in Japanese men and women.

\begin{tabular}{|c|c|c|c|c|c|c|c|c|c|c|c|c|}
\hline \multirow{2}{*}{$\begin{array}{l}\text { Age } \\
\text { (years) }\end{array}$} & \multicolumn{6}{|c|}{ Men } & \multicolumn{6}{|c|}{ Women } \\
\hline & $n$ & $130<$ & $150<$ & $160<$ & $190<$ & $220<$ & $n$ & $130<$ & $150<$ & $160<$ & $190<$ & $220<$ \\
\hline $0-9$ & 522 & 8.6 & 3.0 & 1.7 & 0.0 & 0.0 & 477 & 11.7 & 3.1 & 1.5 & 0.0 & 0.0 \\
\hline $10-19$ & 1489 & 9.8 & 2.8 & 1.2 & 0.1 & 0.0 & 1451 & 12.6 & 3.3 & 1.6 & 0.1 & 0.0 \\
\hline $20-29$ & 766 & 20.1 & 8.4 & 5.0 & 0.0 & 0.1 & 491 & 13.4 & 5.7 & 4.3 & 0.4 & 0.0 \\
\hline 30-39 & 2323 & 30.8 & 14.5 & 9.1 & 0.6 & 0.0 & 1408 & 17.2 & 6.6 & 3.5 & 0.2 & 0.0 \\
\hline $40-49$ & 6598 & 37.2 & 17.9 & 11.5 & 0.8 & 0.0 & 3439 & 31.4 & 13.9 & 8.4 & 0.8 & 0.0 \\
\hline $50-59$ & 4699 & 40.3 & 19.1 & 11.9 & 0.7 & 0.0 & 3395 & 53.6 & 29.1 & 18.3 & 1.5 & 0.0 \\
\hline $60-69$ & 2401 & 37.0 & 17.9 & 11.0 & 0.9 & 0.0 & 2536 & 56.6 & 31.3 & 20.7 & 2.1 & 0.0 \\
\hline $70-79$ & 573 & 38.7 & 20.0 & 10.5 & 0.5 & 0.0 & 618 & 55.0 & 28.3 & 17.3 & 1.8 & 0.0 \\
\hline $80+$ & 63 & 41.3 & 19.0 & 4.8 & 0.0 & 0.0 & 75 & 60.0 & 34.6 & 25.3 & 0.0 & 0.0 \\
\hline $20-79$ & 17360 & 34.0 & 16.3 & 9.8 & 0.6 & 0.0 & 11887 & 37.9 & 19.2 & 12.1 & 1.1 & 0.0 \\
\hline
\end{tabular}

obtained just after World War II, the total fat and animal fat intake increased 3-fold from $18 \mathrm{~g}$ in 1950 to $36 \mathrm{~g}$ in 1965 and to $55.6 \mathrm{~g}$ per day in 1980 , and remained almost unchanged at $56.9 \mathrm{~g}$ per day in 1990 . In Japan, the proportion of calories consumed as fat increased from $7.7 \%$ in 1950 to $14.8 \%$ in 1965 and to $23.6 \%$ in 1982 , and $25.3 \%$ in 1990 . The total calories consumed increased from 2,096 Kilocalories in 1960 to 2,210 Kilocalories in 1970, and decreased to 2,026 Kilocalories in 1990 . Concomitantly, the mean serum cholesterol levels increased by $8 \mathrm{mg} / \mathrm{dl}$ in men (from 184 to 192 $\mathrm{mg} / \mathrm{dl}$ ) and $10 \mathrm{mg} / \mathrm{dl}$ in women (from 186 to $196 \mathrm{mg} / \mathrm{dl}$ ) in all age groups from 1960 to 1980 , and remained unchanged during the subsequent 10-year period (4-6). CHD morbidity per 100,000 persons gradually increased by 3 -fold from 34 in 1960 to 106 in 1980, but remained almost unchanged at 112 in 1990 (15). In Tanushimaru, the serum cholesterol level was $150 \mathrm{mg} / \mathrm{dl}$ in 1958 (1) and increased to $190 \mathrm{mg} / \mathrm{dl}$ in 1990 (15) due to changes in eating habits and lifestyle (15). Thus, the westernization of dietary habits prevailed in Japan from 1960 to 1980, with this trend plateauing from 1980 though 1990. The use of lipid-lowering drugs or of sex hormones, obesity, physical activity, and other dietary factors may have 
Serum Lipid Levels in Japanese Population

Table 13. Serum cholesterol levels $(\mathrm{mg} / \mathrm{dl})$ in the Japanese population.

\begin{tabular}{|c|c|c|c|c|c|c|c|c|c|c|c|c|c|}
\hline \multirow{2}{*}{\multicolumn{2}{|c|}{ Sex/Age (yrs) }} & \multicolumn{3}{|c|}{1960} & \multicolumn{3}{|c|}{1970} & \multicolumn{3}{|c|}{1980} & \multicolumn{3}{|c|}{1990} \\
\hline & & \multirow{2}{*}{$\begin{array}{c}\mathrm{n} \\
7\end{array}$} & \multirow{2}{*}{$\begin{array}{c}\text { Mean } \\
163\end{array}$} & \multirow[t]{2}{*}{ SD } & \multirow[t]{2}{*}{$\mathrm{n}$} & \multirow[t]{2}{*}{ Mean } & \multirow[t]{2}{*}{ SD } & \multirow{2}{*}{$\frac{n}{357}$} & \multirow{2}{*}{$\begin{array}{c}\text { Mean } \\
173\end{array}$} & \multirow{2}{*}{$\frac{S D}{27}$} & \multirow{2}{*}{$\frac{n}{528}$} & \multirow{2}{*}{$\begin{array}{c}\text { Mean } \\
170\end{array}$} & \multirow{2}{*}{$\frac{S D}{25}$} \\
\hline Men & $0-9$ & & & & & & & & & & & & \\
\hline & $10-19$ & 135 & 149 & & 2 & 176 & 30 & 779 & 160 & 28 & 1495 & 170 & 26 \\
\hline & $20-29$ & 372 & 170 & & 103 & 182 & 36 & 509 & 185 & 37 & 763 & 180 & 30 \\
\hline & $30-39$ & 250 & 182 & & 239 & 188 & 33 & 892 & 193 & 35 & 2234 & 191 & 32 \\
\hline & $40-49$ & 374 & 181 & & 1043 & 194 & 45 & 1522 & 198 & 37 & 6489 & 196 & 31 \\
\hline & $50-59$ & 233 & 188 & & 623 & 181 & 45 & 1065 & 201 & 38 & 4613 & 198 & 31 \\
\hline & $60-69$ & 141 & 191 & & 334 & 169 & 43 & 588 & 199 & 40 & 2391 & 194 & 31 \\
\hline & $70-79$ & 29 & 193 & & 97 & 157 & 40 & 282 & 190 & 38 & 579 & 194 & 30 \\
\hline & $80+$ & 8 & 202 & & & & & 114 & 183 & 39 & 65 & 191 & 30 \\
\hline \multirow[t]{9}{*}{ Women } & $0-9$ & 4 & 173 & & & & & 313 & 178 & 29 & 481 & 173 & 24 \\
\hline & $10-19$ & 205 & 167 & & 9 & 198 & 15 & 761 & 170 & 28 & 1459 & 177 & 27 \\
\hline & $20-29$ & 327 & 174 & & 96 & 185 & 39 & 516 & 174 & 34 & 494 & 177 & 29 \\
\hline & $30-39$ & 97 & 178 & & 184 & 184 & 42 & 588 & 178 & 32 & 1417 & 179 & 28 \\
\hline & $40-49$ & 103 & 175 & & 377 & 179 & 36 & 697 & 192 & 36 & 3490 & 191 & 30 \\
\hline & $50-59$ & 62 & 211 & & 273 & 194 & 44 & 718 & 212 & 39 & 3535 & 208 & 31 \\
\hline & $60-69$ & 57 & 194 & & 142 & 199 & 46 & 589 & 213 & 37 & 2637 & 210 & 30 \\
\hline & $70-79$ & 8 & 183 & & 33 & 189 & 44 & 388 & 209 & 40 & 639 & 209 & 31 \\
\hline & $80+$ & 3 & 205 & & & & & 214 & 195 & 40 & 74 & 207 & 37 \\
\hline
\end{tabular}

Table 14. Serum triglyceride levels $(\mathrm{mg} / \mathrm{dl})$ in the Japanese population.

\begin{tabular}{|c|c|c|c|c|c|c|c|c|c|c|c|c|c|}
\hline \multirow{2}{*}{\multicolumn{2}{|c|}{ Sex/Age (yrs) }} & \multicolumn{3}{|c|}{1960} & \multicolumn{3}{|c|}{1970} & \multicolumn{3}{|c|}{1980} & \multicolumn{3}{|c|}{1990} \\
\hline & & $\mathrm{n}$ & Mean & SD & $\mathrm{n}$ & Mean & SD & $\mathrm{n}$ & Mean & SD & $n$ & Mean & SD \\
\hline \multirow[t]{9}{*}{ Men } & $0-9$ & & & & & & & 354 & 65 & 22 & 528 & 55 & 31 \\
\hline & $10-19$ & & & & 2 & 84 & 37 & 781 & 78 & 36 & 1495 & 61 & 34 \\
\hline & $20-29$ & & & & 103 & 98 & 45 & 512 & 100 & 50 & 763 & 94 & 47 \\
\hline & $30-39$ & & & & 239 & 112 & 69 & 895 & 116 & 63 & 2234 & 109 & 52 \\
\hline & $40-49$ & & & & 1043 & 106 & 58 & 1528 & 119 & 63 & 6489 & 109 & 51 \\
\hline & $50-59$ & & & & 623 & 98 & 54 & 1074 & 120 & 62 & 4613 & 110 & 51 \\
\hline & $60-69$ & & & & 334 & 96 & 72 & 591 & 117 & 64 & 2391 & 105 & 47 \\
\hline & $70-79$ & & & & 97 & 74 & 31 & 280 & 117 & 52 & 579 & 95 & 40 \\
\hline & $80+$ & & & & & & & 114 & 109 & 44 & 65 & 88 & 37 \\
\hline \multirow[t]{9}{*}{ Women } & $0-9$ & & & & & & & 314 & 69 & 24 & 481 & 56 & 25 \\
\hline & $10-19$ & & & & 9 & 105 & 29 & 762 & 86 & 34 & 1459 & 63 & 31 \\
\hline & $20-29$ & & & & 96 & 89 & 42 & 513 & 85 & 36 & 494 & 63 & 29 \\
\hline & $30-39$ & & & & 184 & 98 & 48 & 588 & 79 & 34 & 1417 & 69 & 34 \\
\hline & $40-49$ & & & & 377 & 104 & 54 & 705 & 91 & 44 & 3490 & 77 & 37 \\
\hline & $50-59$ & & & & 273 & 118 & 60 & 731 & 107 & 51 & 3535 & 96 & 45 \\
\hline & $60-69$ & & & & 142 & 132 & 77 & 591 & 126 & 64 & 2637 & 105 & 46 \\
\hline & $70-79$ & & & & 33 & 109 & 54 & 396 & 122 & 54 & 639 & 102 & 44 \\
\hline & $80+$ & & & & & & & 217 & 106 & 40 & 74 & 99 & 42 \\
\hline
\end{tabular}

Serum triglyceride levels were not measured in 1960.

contributed to the observed lack of change in serum total cholesterol levels.

Although the reliability with which trends in lipid measurements can be assessed depends on knowledge of comparability of the measurements in the four surveys, the methods for cholesterol measurement were different in each survey. However, the accuracy of the measurements was indirectly monitored through the CDC Lipid Laboratory Standardization Program (11), and the cholesterol levels measured by the methods in two consequent surveys were comparable.
There have been many studies of nationwide reference values of serum cholesterol and triglyceride. In the present survey as well as the earlier surveys in Japan (4-6) and the US $(3,14)$, higher cholesterol levels were observed in men than in women from 20 to 50 years of age. The higher levels in men compared with women and the tendency in women towards higher levels in the older age groups have been reported repeatedly, similarly to our findings.

Physiological effects, especially female sex hormones might have reduced both serum cholesterol and triglyceride 
Table 15. Serum cholesterol levels (mg/dl) in Japan and USA from 1960 through 1990.

\begin{tabular}{|c|c|c|c|c|c|c|c|c|c|c|c|c|c|}
\hline \multirow{2}{*}{\multicolumn{2}{|c|}{ Sex/Age }} & \multicolumn{3}{|c|}{1960} & \multicolumn{3}{|c|}{1970} & \multicolumn{3}{|c|}{1980} & \multicolumn{3}{|c|}{1990} \\
\hline & & Japan & USA & Difference & Japan & USA & Difference & Japan & USA & Difference & Japan & USA & Difference \\
\hline \multirow[t]{6}{*}{ Male } & $20-29$ & 170 & 198 & -28 & 182 & 194 & -12 & 177 & 192 & -15 & 180 & 189 & -9 \\
\hline & $30-39$ & 182 & 227 & -45 & 188 & 221 & -33 & 192 & 217 & -25 & 191 & 207 & -16 \\
\hline & $40-49$ & 181 & 231 & -50 & 194 & 229 & -35 & 197 & 227 & -30 & 196 & 218 & -22 \\
\hline & $50-59$ & 188 & 233 & -45 & 181 & 229 & -48 & 199 & 229 & -30 & 198 & 221 & -23 \\
\hline & $60-69$ & 191 & 230 & -39 & 169 & 226 & -57 & 193 & 221 & -28 & 194 & 218 & -24 \\
\hline & $70-79$ & 193 & & & 157 & & & 192 & & & 194 & 205 & -11 \\
\hline \multirow[t]{6}{*}{ Female } & $20-29$ & 174 & 194 & -20 & 185 & 191 & -6 & 173 & 189 & -16 & 177 & 185 & -8 \\
\hline & $30-39$ & 178 & 214 & -36 & 184 & 207 & -23 & 178 & 207 & -29 & 179 & 195 & -16 \\
\hline & $40-49$ & 175 & 237 & -62 & 179 & 232 & -53 & 191 & 232 & -41 & 191 & 217 & -26 \\
\hline & $50-59$ & 211 & 262 & -51 & 194 & 245 & -51 & 211 & 249 & -38 & 208 & 237 & -29 \\
\hline & $60-69$ & 194 & 266 & -72 & 199 & 250 & -51 & 214 & 246 & -32 & 210 & 234 & -24 \\
\hline & $70-79$ & 184 & & & 189 & & & 211 & & & 209 & 230 & -21 \\
\hline
\end{tabular}

Table 16. Intake of nutrients in the Japanese population.

\begin{tabular}{|c|c|c|c|c|c|c|c|c|}
\hline & \multirow[t]{2}{*}{1960} & \multicolumn{3}{|c|}{1970} & \multirow[t]{2}{*}{1980} & \multicolumn{3}{|c|}{1990} \\
\hline & & $\%$ & & $\%$ & & $\%$ & & $\%$ \\
\hline Total Kilocalories & 2096 & 100.0 & 2210 & 100.0 & 2119 & 100.0 & 2026 & 100.0 \\
\hline Carbohydrate (g) & 399.0 & 76.1 & 368.0 & 66.6 & 309.0 & 61.5 & 287.0 & 59.2 \\
\hline Protein & 69.7 & 13.3 & 77.6 & 14.0 & 78.7 & 14.9 & 78.7 & 15.5 \\
\hline Total fat & 24.7 & 10.6 & 46.5 & 18.9 & 55.6 & 23.6 & 56.9 & 25.3 \\
\hline Animal fat $(\mathrm{g})$ & $\cdots \cdots$ & $\cdots \cdots$ & 20.9 & & 26.9 & & 27.5 & \\
\hline
\end{tabular}

levels in the females from 20 to 50 years of age, although most Japanese women have not received estrogen replacement therapy since its use for contraceptive purposes is not permitted in Japan. HDL-cholesterol levels were higher in females than in males above 10 years of age. Therefore, the LDL-cholesterol levels in the females were lower than those in the males at 20 to 49 years of age and higher in those 0 to 19 years of age and over 50 years. The drop in serum cholesterol levels in the teenage years reported in the US $(16)$ and earlier Japan surveys $(3,5)$ was not observed in the present study.

The National Health and Nutrition Examination Surveys (NHANES) (3) provide periodic information on the health and nutritional status of the civilian non-institutionalized population of the United States. The mean serum total cholesterol levels in US adults from 20 through 74 years of age have consistently declined over time from $1991(3,17)$. This decline occurred across the entire distribution of serum cholesterol levels and in all age and sex groups. These findings suggest that public health programs designed to reduce serum cholesterol levels are proving successful in the United States (18). The observed downward trend in serum cholesterol levels has coincided with a continuing decline in coronary heart disease mortality (19).

In 1980 and 1989, the National Survey on Circulatory Disorders was conducted in Japan to determine the prevalence of risk factors for cardiovascular diseases in the same population as the annual Japanese Nutrition Survey (20). Between 1980 and 1989, age-adjusted serum cholesterol levels increased from 186 to $201 \mathrm{mg} / \mathrm{dl}$ for men and from 189 to $202 \mathrm{mg} / \mathrm{dl}$ for women. The increase in serum cholesterol levels is contrary to the downward trends seen in mortality from coronary heart disease (21). Energy supply from dietary fat increased from $23.4 \%$ to $25.1 \%$, but the expected change in serum cholesterol levels from Keys' equation (22) was 2.6 $\mathrm{mg} / \mathrm{dl}$, which could account for only $20 \%$ of the weighted mean of the difference for both sexes $(13.5 \mathrm{mg} / \mathrm{dl})$. Moreover, blood samples in the survey were not necessarily obtained under fasting conditions (20), making serum lipid levels higher than those in the present study. Regional heterogeneity of serum lipid concentration such as low serum cholesterol levels in the Tohoku area (northern Japan) might have produced the discrepancy between the National Survey on Circulatory Disorders (20) and the present study.

Tracking of national, regional, and occupational cholesterol levels and coronary disease rates may be instructive in Asia, particularly where urbanization has become associated with adoption of a sedentary lifestyle. In the earlier surveys in Japan, serum lipid determinations were carried out at various institutions (4-6), and thus, there is evidence of considerable interclinic variation. However, in the present survey, measurements of lipid level were performed at a single laboratory. The observed interclinic differences may be attributed in part to the distribution of lipid influencing factors such as genetic, dietary, and other environmental factors.

Attention to standardized national, international, migrant, and demonstration projects in addition to clinical trials of 
lipid-lowering regimens will be particularly helpful in tracking and controlling the course of heart disease in the future. The present results will represent the standard lipid level data for the Japanese population, and subsequent 10-year surveys will clarify the trends of lipid levels and $\mathrm{CHD}$ rates in this country.

Acknowledgments: This work was supported in part by the grant of HMG-CoA Reductase Study Group Foundation of Sankyo Co. We wish to thank the Special Research Laboratory (SRL) for performing measurement of serum lipids and apolipoproteins.

\section{References}

(1) Keys A: Coronary heart disease in seven countries. Circulation, 41 (suppl 1) : 1-199, 1970

(2) Marmot MG, Syme SL, Kagan A, Kato H, Cohen JB, and Belsky $\mathrm{J}$ : Epidemiologic studies of coronary heart disease and stroke in Japanese men living in Japan, Hawaii and California. Am J Epidemiol, 102 : 514-525, 1975

(3) Johnson CL, Rifkind BM, Sempos CT, Carroll MD, Bachorik PS, Briefel RR, Gordon DJ, Burt VL, Brown CD, Lippel K, and Cleeman $\mathrm{Jl}$ : Declining serum total cholesterol levels among US adults. The National Health and Nutrition Examination Surveys. JAMA, 269 : 3002-3008, 1993

(4) Research Committee on Atherosclerosis in Japan (Chairman : Okinaka S) : Total serum cholesterol levels in normal subjects in Japan. Jpn Circ J, 29: 505-510, 1965

(5) Research Committee on Hyperlipidemia in Japan (Chairman : Oshima K): Total serum cholesterol and triglyceride levels in normal subjects in Japan. J Jpn Atheroscler Soc, 1: 101-108, 1973 (in Japanese)

(6) Research Committee on Familial Hyperlipidemia in Japan (Chairman : Sekimoto H) : Changes of serum total cholesterol and triglyceride levels in normal subjects in Japan in the past twenty years. Jpn Circ J, 47: 1351-1358, 1983

(7) Allain CC, Poon LS, Chan CSG, Richmond W, and Fu PC: Enzymatic determination of total serum cholesterol. Clin Chem, 20 : 470-475, 1974

(8) Sugiura M, Oikawa T, Hirano K, Maeda $H$, Yoshimura $H$, Sugiyama $M$, and Kuratsu $T$ : A simple colorimetric method for determination of serum triglycerides with lipoprotein lipase and glycerol dehydrogenase. Clin Chim Acta, 81: 125-130, 1977

(9) Kajikawa T, Ishiki R, Nakao Y, Kushiro H, Kodama J, Nanbu S, and Yamamoto A : Determination of high density lipoprotein cholesterol by heparin- $\mathrm{Ca}^{2+}$ precipitation and enzymatic measurement. J Jpn Atheroscler Soc, 9: 393398, 1981 (in Japanese)

(10) Friedewald WT, Levy RI, and Fredrickson DS : Estimation of the concentration of low density lipoprotein cholesterol in plasma without use of the preparative ultracentrifuge. Clin Chem, 18: 499-502, 1972

(11) Laboratory Methods Committee of the Lipid Research Clinics Program of the National Heart, Lung, and Blood Institute: Cholesterol and triglyceride concentrations in serum/plasma pairs. Clin Chem, 23: 60-63, 1977

(12) Health and Welfare Statistics Association: Kousei-noShihyou 41: 468, 1994 (in Japanese)

(13) Ibid : $41: 456,1994$
(14) National Center for Health Statistics-National Heart Lung, and Blood Institute Collaborative Lipid Group: Trends in serum cholesterol levels among US adults aged 20 to 74 years. Data from the National Health and Nutrition Examination Surveys, 1960 to $1980 . \quad$ JAMA, 257 : 939-942, 1987

(15) The Lipid Research Clinics Program Epidemiology Committee: Plasma lipid distribution in selected North America populations: The Lipid Research Clinics Program Prevalence Study. Circulation, 60: 427-439, 1979

(16) Toshima $\mathrm{H}$ : Coronary artery disease trends in Japan. Jpn Circ J, 58: 166-172, 1994

(17) Sempos CT, Cleeman Jl, Carroll MD, Johnson CL, Bachorik PS, Gordon DJ, Burt VL, Briefel RR, Brown CD, Lippel K, and Rifkind BM: Prevalence of high blood cholesterol among US adults. An update based on guidelines from the second report of the National Cholesterol Education Program Adult Treatment Panel. JAMA, 269 : 3009-3014, 1993

(18) National Cholesterol Education Program: Report of the NCEP Expert Panel on Detection, Evaluation, and Treatment of High Blood Cholesterol in Adults. Arch Intern Med, 148: 36-39, 1988

(19) Levy RI: Declining mortality in coronary heart disease. Arteriosclerosis, 1: 312-325, 1981

(20) Ministry of Health and Welfare: National Survey on Circular Disorders. 1989. Daiichi Shuppan, Tokyo, 1991

(21) Okayama A, Ueshima H, Marmot MG, Nakamura M, Kita Y, and Yamakawa $\mathrm{M}$ : Changes in total serum cholesterol and other risk factors for cardiovascular disease in Japan, 19801989. Int J Epidemiol, 22 : 1038-1047, 1993

(22) Keys A, Anderson JT, and Grande F: Serum cholesterol response to changes in the diet. IV. Particular saturated fatty acids in the diet. Metabolism, 14: 776-787, 1965

\section{Appendix}

\section{Research Committee on Serum Lipid Level Survey 1990 in Japan}

Chairmen: Akira Yamamoto, M.D. (Dept. of Etiology and Pathophysiology, National Cardiovascular Research Inst.);

Haruo Nakamura, M.D. (1st Dept. of Internal Med., National Defense Medical College);

The late Tadao Yasugi, M.D. (2nd Dept. of Internal Med., School of Med., Nihon Univ.)

Principal investigators : Hiroshi Mabuchi, M.D. (2nd Dept. of Internal Med., School of Med., Kanazawa Univ.);

Toru Kita, M.D. (Dept. of Clin. Bio-Regulatory Science, Faculty of Med., Kyoto Univ.);

Yuji Matsuzawa, M.D. (2nd Dept. of Internal Med., School of Med., Osaka Univ.);

Noriaki Nakaya, M.D. (Tokyo Hospital, 1st Dept. of Internal Med., School of Med., Tokai Univ.);

Yasushi Saito, M.D. (2nd Dept. of Internal Med., School of Med., Chiba Univ.);

Hiroshi Horibe, M.D. (Dept. of Health \& Psychosocial Med, Aichi Med. School).

Advisers : Yuichiro Goto, M.D. (Dept. of Internal Med., School of Med., Tokai Univ.);

Hiroshi Sekimoto, M.D. (Dept. of Geriatrics, Kanazawa Med. College) 
Co-principal investigators (Institutes) : O. limura, M.D. (2nd Dept. of Internal Med., School of Med., Sapporo Med. Univ.), I. Makino, M.D. (2nd Dept. of Internal Med., Asahikawa Med. School), T. Toyota, M.D. (3rd Dept. of Internal Med., School of Med., Tohoku Univ.), Y. Maruhama, M.D. (1st Dept. of Internal Med., Iwate Med. School), Y. Saito, M.D. (2nd Dept. of Internal Med., School of Med., Chiba Univ.), H. Nakamura, M.D. (1st Dept. of Internal Med., National Defense Medical College), E. Saito, M.D. T. Fujioka, M.D. (2nd Dept. of Internal Med., School of Med., Nihon Univ.), N. Nakaya, M.D. (Tokyo Hospital, 1st Dept. of Internal Med., School of Med., Tokai Univ.), M. Ookuni, M.D. (Dept. of Pediatrics, School of Med., Nihon Univ.), M. Murata, M.D. (Dept. of Pediatrics, Tokyo Womens' Medical College Daini Hospital), T. Abe, M.D. (Dept. of Pediatrics, School of Med., Teikyo Univ.), H. Hamaguchi, M.D. (Dept. of Human Genetics, Institute of Basic Med. Sciences, Univ. of Tsukuba ), T. Murase, M.D. (Dept. of Endocrinol. and Metabol., Toranomon Hospital), F. Kuzuya, M.D. (Dept. of Geriatrics, School of Med., Nagoya Univ.), N. Sakuma, M.D. (3rd Dept. of Internal Med., School of Med., Nagoya City Univ.), H. Horibe, M.D. (Dept. of Health \& Pscychosocial Med., Aichi Med. School), H. Mabuchi, M.D. (2nd Dept. of Internal Med., School of Med., Kanazawa Univ.), T. Nakai, M.D. (3rd Dept. of Internal Med., Fukui Med. School), Y. Matsuzawa, M.D. (2nd Dept. of Internal Med., School of Med., Osaka Univ.), A. Yamamoto, M.D., T. Yamamura, M.D. (Dept. of Etiology and Pathophysiology, National Cardiovascular Research Inst.), M. Tshushima, M.D. (Dept. of Med., Div. of
Atherosclerosis \& Metabolism, National Cardiovascular Research Inst.), M. Konishi, M.D. (Dept. of Public Screening, National Cardiovascular Research Inst.), T. Kita, M.D. (Dept. of Clin. Bio-Regulatory Science, Faculty of Med., Kyoto Univ.);

M. Yokoyama, M.D. (1st Dept. of Internal Med., School of Med., Kobe Univ.), S. Yukawa, M.D. (3rd Dept. of Internal Med., School of Med., Wakayama Univ.), M. lida, M.D. (Dept. of Internal Med., Osaka Prefectural Adult Disease Center), G. Kajiyama, M.D. (1st Dept. of Internal Med., School of Med., Hiroshima Univ.), G. Egusa, M.D. (2nd Dept. of Internal Med., School of Med., Hiroshima Univ.), C. Mori, M.D. (Dept. of Pediatrics, Shimane Med. School), F. Okuda, M.D. (2nd Dept. of Internal Med., School of Med., Yamaguchi Univ.), K. Ishikawa, M.D. (Dept. of Internal Med., Kure National Hospital), K. Arakawa, M.D. (2nd Dept. of Internal Med., School of Med., Fukuoka Univ.), H. Toshima, M.D. (Kurume Univ. Med. Center), K. Nonaka, M.D. (Division of Endocrinol. and Metabol., Dept. of Medicine, School of Med., Kurume Univ.), K. Yamamoto, M.D. (Dept. of Internal Med., Saga Med. School), M. Shichiri, M.D. (Dept. of Metabolic Med., School of Med., Kumamoto Univ.), H. Tanaka, M.D. (1st Dept. of Internal Med., School of Med., Kagoshima Univ.), K. Hiwada, M.D. (2nd Dept. of Internal Med., School of Med., Ehime Univ.), T. Suehiro, M. D. (2nd Dept. of Internal Med., Kochi Med. School), H. Miki, M.D. (3rd Dept. of Internal Med., Kagawa Med. School), G. Mimura, M.D. (2nd Dept. of Internal Med., School of Med., Ryukyu Univ.) 